\title{
Pharmaco-chemical profiling of Desmodium gangeticum (L.) DC. with special reference to soil chemistry
}

\author{
Prasobh K. Mohan ${ }^{1 *}$ (D, T. P. Adarsh Krishna ${ }^{2}$, T. Senthil Kumar ${ }^{1}$ and B. D. Ranjitha Kumari ${ }^{{ }^{*}}$
}

\begin{abstract}
Background: Desmodium gangeticum (L.) DC. (Fabaceae) (DG) is a perennial non-climbing herb or shrub and folklore medicine, widely shows a large number of medicinal properties, as well as contains divergent bioactive compounds. Many of the herbal formulations contain this medicinal plant, which is considered as master of medicinal plant in Ayurveda. This study is an attempt to establish this plant material based on its pharmaco-chemical profiles with special reference to soil chemistry. The pharmaco-chemical features such as organoleptic, DNA sequence, physicochemical, proximate, phytochemical, UV, and FTIR profiling were carried out using standard techniques. Moreover, the ADME-PK properties of the selected molecules were established.

Results: The pharmaco-chemical features like organoleptic, DNA sequence, physicochemical, proximate, phytochemical, UV, and FTIR profiling, ADME-PK properties, and soil chemistry of D. gangeticum revealed its unique and diagnostic peculiarities. DNA barcoding showed that the sequence was $99.77 \%$ similar to D. gangeticum (KP094638) having 100\% query coverage. The soil analysis revealed the presence of moderately high content of NPK and sufficient amount of all essential macro- and micronutrients ( $\mathrm{S}, \mathrm{Fe}, \mathrm{Mn}, \mathrm{Cu}, \mathrm{Zn}$, and B). The phytochemical profiling showed that the ethanolic extract of the aerial part contained glycoside, amino acid, phenols, alkaloids, flavonoids, and coumarins, while the ethanolic root extract of the plant revealed the presence of glycoside, amino acid, phenols, alkaloids, flavonoids, coumarins, and triterpenoids. FTIR results indicated that the plant extracts are mainly rich in phe-

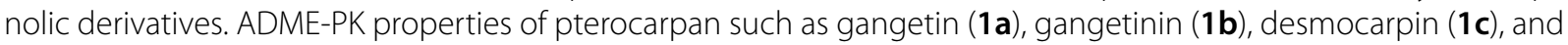
desmodin (1d) were found to pass the Lipinski, Ghose, Veber, and Egan rules, supporting the drug-likeliness.

Conclusion: This is the first record of pharmaco-chemical profiling of D. gangeticum along with soil chemistry, and this information helps in the proper identification and future studies on this species.
\end{abstract}

Keywords: D. gangeticum, Soil chemistry, Pharmaco-chemical profiling, ADME-PK properties

\section{Background}

Recently, the importance of plant-based drugs and their therapeutic activities has high scope and has attracted great attention in the world [1]. The herbs contain various classes of complex molecules, which show good chemical biology [2]. A large population in many

\footnotetext{
*Correspondence: prasobhm8@gmail.com; ranjithakumari2004@yahoo.co.in ${ }^{1}$ Department of Botany, Bharathidasan University, Tiruchirappalli, Tamil Nadu 620 024, India

Full list of author information is available at the end of the article
}

countries depends on herbal drugs for the treatment of several health problems [3]. In the present scenario, scientists have been focused to develop herbal formulations, especially to improve our immune system for preventing viral infections like the novel COVID-19 $[4,5]$. The herbal formulation has various ingredients, which show great potential against various disorders [6-9].

Herbal drugs are a combination of complex or active mixtures of one or more plants. Lack of standardization and quality control of herbal drugs affects their actual potencies (efficiencies). Most of the drugs are in the 
form of crude extracts or powders which are a mixture of several components in the crude or processed state, and the active pharmacophore when isolated individually sometimes failed to give the desired action [10]. This implies that the pharmacological activity of the drugs is the synergistic effect of two or more components. The quality of herbal drugs depends on harvesting time and processing methods. There are few official guidelines for herbal formulation. Moreover, who are working on this field have their own parameters [11]. So, it is necessary to know the actual quality and purity of crude drugs before the formulation process. The standardization of herbal drug ingredients based on the pharmaco-chemical properties can lead to the dose determination, quality, and purity of drugs.

Desmodium gangeticum (L.) DC. (Figure 1) belongs to the family Leguminosae (Fabaceae), subfamily Papillionaceae. The member of the genus Desmodium contains 170 tropical and subtropical species [12]. It is a perennial erect or ascending prostrate under shrub, distributed throughout the warmer parts of India. Matured plants are $60-130 \mathrm{~cm}$ high with angular branches, pubescent or glabrous. Leaves are simple, variable, ovate-oblong, or rounded in shape, $3-14 \mathrm{~cm} \times 2-7 \mathrm{~cm}$, acute to acuminate, glabrous above, pubescent beneath; petioles $1-2.5 \mathrm{~cm}$ long. Flowers are purple or white in color [13]. Many members of this genus have been used as traditional medicines [14], and chemical investigations have revealed the presence of isoflavones, isoflavanones, C-glycosyl flavonoids, pterocarpans, and coumaronochromones $[13,15,16]$. Looking into the species, $D$. gangeticum have exhibited many therapeutic properties.

In Ayurveda medicine, this plant species D. gangeticum is the chief of the ten ingredients in the "Dasamula kwatha," which is used as a health tonic and pain reliever [17]. Moreover, in Unani medicine "Arq dashmul" contains this species roots extract and used against leucorrhoea and for pains due to cold [18]. From our preliminary field investigation, we found that many tribes from the Western Ghats region of Kerala used this plant for the treatment of various ailments such as fever, typhoid fever, cough, diuretic, inflammations, cough, asthma, and dysentery.

The high medicinal properties of this species have been attracting considerable interest in its industrial expansion. However, it made it difficult to meet the increasing market demand. Due to the increasing demand for herbal medicine, adulteration of genuine herbs with low-grade ones had increased significantly. [19]. It will affect the therapeutic efficiency of the drug. Therefore, it is a great interest to carry out a screening of $D$. gangeticum to validate their pharmaco-chemical profile.
The standardization of herbal drugs is laid down for the pharmaco-chemical parameters. Depending on the geographic area and climate, the parameters may change [20]. In this aspect, here we disclosed the pharmacochemical analysis of $D$. gangeticum with special reference to soil chemistry.

\section{Methods}

\section{Plant collection and processing}

Desmodium gangeticum (L.) DC. was collected from the Idukki District of Kerala, India, during March-April 2019 (the atmospheric temperature found to be $25-33^{\circ} \mathrm{C}$ with a humidity of $74 \%$ ). The plant was identified by Dr. S. Soosairaj, Department of Botany, St. Joseph's College, Tiruchirappalli, Tamil Nadu, India (voucher number: 3006). Freshly collected plant material was cleaned to remove adhering dust, divided into different parts, and then dried under shade. The dried samples were powdered and stored at room temperature $\left(25^{\circ} \mathrm{C}\right)$ for further studies.

\section{Reagents and chemicals}

All the reagents and chemicals used in this research work were procured from M/s Merck India, Ltd., Godrej One, 8th floor, Pirojsha Nagar, Eastern Express Highway, Vikroli East, Mumbai, Maharashtra 400079.

\section{DNA Barcoding \\ DNA extraction}

Genomic DNA was extracted from young leaves of $D$. gangeticum using a modified cetyl trimethyl ammonium bromide (CTAB) method [21]. The quantity of DNA was measured using a NanoDrop Spectrophotometer (ND2000, Thermo Scientific, Wilmington, USA), and the quality of DNA was checked via a $0.8 \%(w / v)$ agarose gel electrophoresis. The isolated DNA was stored at $-20^{\circ} \mathrm{C}$.

\section{DNA amplification}

The PCR was set with $50 \mu \mathrm{l}$ reaction mixture containing 300 ng genomic DNA, $25 \mathrm{mM} \mathrm{MgCl}, 1 \mathrm{mM}$ dNTPs, 10 pmol rbcL primer (rbcL [R]: GTAAAATCAAGTCCA CCRCG; rbcL [F]: ATGTCACCACAAACAGAAACT AAAGC), and $1 \mathrm{U}$ Taq DNA polymerase (GeNet Bio, Daejeon, Korea). The PCR was performed using a master cycler (Eppendorf, Germany) with an initial denaturation at $94{ }^{\circ} \mathrm{C}$ for $5 \mathrm{~min}$, followed by 35 cycles of $30 \mathrm{~s}$ denaturation at $94{ }^{\circ} \mathrm{C}, 45 \mathrm{~s}$ annealing at $54{ }^{\circ} \mathrm{C}$, and $45 \mathrm{~s}$ extension at $72{ }^{\circ} \mathrm{C}$, with a final extension at $72{ }^{\circ} \mathrm{C}$ for $5 \mathrm{~min}$. The PCR products were resolved on a $1 \%(\mathrm{w} / \mathrm{v})$ agarose gel at $70 \mathrm{~V}$ and stained with ethidium bromide. The agarose gel was photographed using the ChemiDoc XRS imaging 


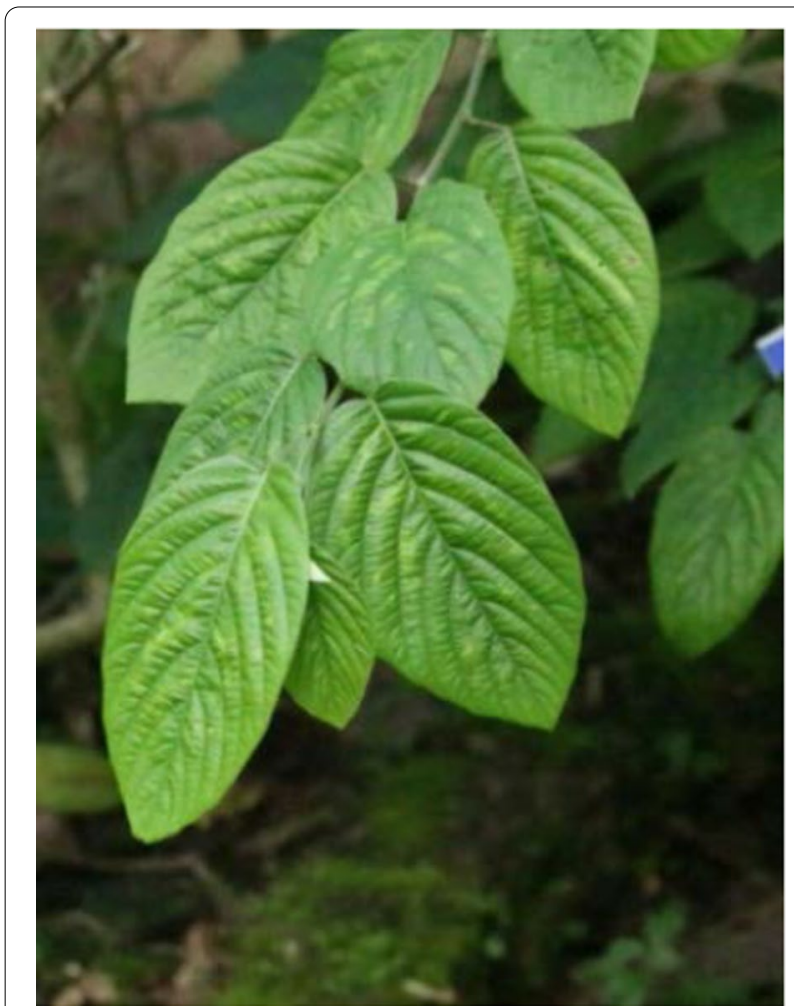

Fig. 1 Wild photograph of D. gangeticum (L.) DC

system (Bio-Rad, Hercules, California, USA) to check the presence or absence of bands.

\section{Sequencing and plant identification}

The amplified products were used for DNA sequencing (sequencing PCR was performed in a final volume of $10 \mu \mathrm{l}$ containing BigDye sequencing buffer (1X), template $40 \mathrm{ng}$ (for 1000-2000 bp amplicon sequencing), primers (3.2 pM), and BigDye $(0.5 \mu \mathrm{l})$ ), and the sequences were processed with BioEdit software version 7.1.11 [22]. The chimeric artifacts were removed using the online tool Decipher [23]. The sequences were compared by using BLASTn (https://blast.ncbi.nlm.nih.gov/Blast.cgi) with the non-redundant database of sequences deposited at the NCBI GenBank database [24].

\section{Soil analysis}

Soil samples were collected from the location of plant population grown (Idukki District of Kerala, India). The soil profile of different depths $(0-10,10-20$, and $20-30 \mathrm{~cm}$ ) was taken using the soil auger. Immediately after collection, soil samples were air-dried at room temperature $\left(22 \pm 1{ }^{\circ} \mathrm{C}\right)$, sieved $(2 \mathrm{~mm})$, and analyzed for different soil parameters. The dried sample $(10 \mathrm{~g})$ was used to evaluate the soil $\mathrm{pH}$ [25], electrical conductivity [26], total organic carbon (TOC) by titration method [27], and determination of total NPK and nitrogen [28]. Other elements ( $\mathrm{S}, \mathrm{Fe}, \mathrm{Mn}, \mathrm{Cu}, \mathrm{Zn}$, and $\mathrm{B}$ ) are evaluated by spectrophotometric method [29] and flame photometer [30].

\section{Organoleptic and macroscopic evaluation}

To carry out organoleptic evaluation, various sensory parameters of the plant material, such as color, odor, size, shape, and taste, were studied [31].

\section{Powder microscopy}

The dried powdered aerial parts of D. gangeticum were studied by placing small amounts of powder on a slide and observing under the microscope. Samples were mounted on $5 \%$ glycerin solution or stained with reagents such as N/50 iodine for the observation of starches or $0.1 \% \mathrm{w} / \mathrm{v}$ phloroglucinol plus a drop of concentrated hydrochloric for the observation of lignified cells [32]. Characteristic structures and cell contents such as fibers, vessels, cork cells, calcium oxalate crystals, and plant cells were observed at various magnifications, and photomicrographs were taken.

\section{Physicochemical analysis}

The dried powdered aerial parts and root were used for determination of physicochemical contents, viz. total ash, acid-soluble ash, water-soluble ash, and alcoholsoluble as hand extractive values using different solvents, viz. ethanol, chloroform, ethyl acetate, hexane, toluene, petroleum ether, and water $[19,33]$.

\section{Proximate analysis}

The dried powdered aerial parts and root were used for evaluation of proximate contents through total ash, crude fiber, crude protein, carbohydrate, crude fat, dry matter, and moisture content [34].

\section{Preparation of extracts}

The dried aerial/root (100 g) was powdered in a plant sample grinder at a controlled temperature and used for extraction using suitable solvents in a Soxhlet extraction apparatus attached with a rotary vacuum evaporator (Buchi, Switzerland). Solvents were removed using a rotary vacuum evaporator at 175 mbar at a controlled temperature.

\section{Phytochemical analysis}

Preliminary phytochemical screening was done as per the standard procedure [35] for various phyto-constituents such as steroids (Liebermann-Burchard test), terpenoids 
(Salkowaski test), alkaloids (Mayer's test), tannins (ferric chloride test), flavonoids (alkaline reagent test), carbohydrates (Benedict's test), and amino acids (Biuret test).

\section{UV and FTIR profiling}

The UV spectra of the ethanol extracts of the aerial and root were recorded on a Jasco UV spectrophotometer at a wavelength range of $200-600 \mathrm{~nm}$ with a scan speed of $400 \mathrm{~nm} / \mathrm{min}$. The spectra used in obtaining the structural properties of the selected plant extract were obtained from the Fourier-transform infrared spectrometer equipped with an attenuated total reflectance (ATR-FTIR), model PerkinElmer Spectrum 400. In the ATR-FTIR method, the sample to be analyzed is placed directly into the sample cell, where a good and reproducible contact between the sample and the crystal of reflection is obtained nondestructively, producing goodquality infrared spectra. The FTIR spectra were recorded in the range of $4000-700 \mathrm{~cm}^{-1}$.

\section{ADME properties}

Pharmacokinetics and drug-likeness prediction for the compounds $1 \mathrm{a}-\mathrm{d}$ were performed by online tool SwissADME [36] of the Swiss Institute of Bioinformatics (http://www.sib.swiss) [37]. 2D structural models were drawn in ChemBioDraw Ultra version 15.0 (Cambridge Software), and SMILES of 1a-d was translated into molfile by online SMILES translator and structure file generator found in online tool SwissADME. The analysis task was done to check whether the compound was an inhibitor of isoforms of the Cytochrome P450 (CYP) family, such as CYP1A2, CYP2C19, CYP2C9, CYP2D6, and CYP3A4. Also, pharmacokinetics (such as gastrointestinal absorption, P-glycoprotein, and blood-brain barrier) and drug-likeness prediction was done, such as Lipinski, Ghose, and Veber rules and bioavailability score [38-40]. The Lipinski, Ghose, Egan, Mugges, and Veber rules were applied to assess drug-likeness to predict whether a compound is likely to be bioactive according to some important parameters such as molecular weight, Log P, number of HPA, and HBD. The SwissADME tool used a vector machine algorithm (SVM) [41] with fastidiously cleaned large datasets of known inhibitors/non-inhibitors as well as substrates/non-substrates.

\section{Results}

The chemical profiling of soil is recorded in Table 1. It is found that $\mathrm{pH}$ of the soil is strongly acidic $(\mathrm{pH}=5.21)$ in nature and electrical conductivity was $0.12 \mathrm{dSm}^{-1}$ and a very high content of organic carbon $(1.52 \%)$ was detected. The NPK analysis revealed moderately high content of nitrogen $(\mathrm{N}=446.7 \mathrm{~kg} / \mathrm{ha})$ and very high content of phosphorus $(\mathrm{P}=444.7 \mathrm{~kg} / \mathrm{ha})$ and potassium $(\mathrm{K}=313.4 \mathrm{~kg} / \mathrm{ha})$ in the soil. Furthermore, sulfur (S) analysis showed a sufficient amount of $6.5 \mathrm{ppm}$. Moreover, micronutrient analysis revealed sufficient contents of iron (Fe, $18.3 \mathrm{ppm})$, manganese (Mn, $18.7 \mathrm{ppm})$, copper $(\mathrm{Cu}, 6.17 \mathrm{ppm})$, zinc $(\mathrm{Zn}, 9.95 \mathrm{ppm})$, and boron $(\mathrm{B}$, $2.10 \mathrm{ppm})$.

The macroscopic and organoleptic evaluation is an easy method and is carried out at the time of plant collection. The various observed features of the plant parts were recorded and are depicted in Table 2.

The result of powder microscopy (Fig. 2) reveals the presence of various parts like epidermis (A), tangentially elongated cork cells (B), separated fiber $(\mathrm{C})$, prismatic crystals of calcium oxalate (D), pitted vessel (E), and simple fibers (F). Moreover, we did not find any symptoms of nutrient deficiency, like stunted growth, death of plant tissue, or yellowing of the leaves caused by a reduced production of chlorophyll, a pigment needed for photosynthesis. Additionally, the root structure was found to be normal.

Furthermore, we have used the ribulose-1,5-bisphosphate carboxylase/oxygenase large subunit $(r b c L)$ molecular marker for plant species identification. The NCBI BLAST results showed that the sequence was $99.77 \%$ similar to D. gangeticum (KP094638), and also it showed $100 \%$ query coverage.

The physicochemical parameters such as percentage of moisture content, total ash, and acid insoluble ash were found to be $11.85 \%, 7.38 \%$, and $1.78 \%$ in areal and $11.34 \%, 4.80 \%$, and $0.76 \%$ for root, respectively (Fig. 3). The successive Soxhlet extractive yields obtained from water, followed by ethanol, ethyl acetate, and hexane, are calculated (Table 3).

The proximate parameters such as percentage of crude fiber, crude protein, crude fat, and carbohydrate contents of the aerial and root are also evaluated and are shown in Figure 3. Aerial part has a high content of crude fiber of $11.85 \%$, crude protein of $15.12 \%$, crude fat of $2.24 \%$, and carbohydrate of $63.41 \%$. Root powder has protein of $8.63 \%$ and crude fat of $0.73 \%$. Moreover, the crude fiber (49.83\%) and carbohydrate $(74.44 \%)$ were found to have the highest percent.

The results of the phytochemical profiling (Table 4) showed that the ethanolic extract of the aerial part contained glycoside, amino acid, phenols, alkaloids, flavonoids, and coumarins, while the ethanolic root extract of the plant revealed the presence of glycoside, amino acid, phenols, alkaloids, flavonoids, coumarins, and triterpenoids.

The UV spectra of the ethanolic extract of aerial (A) and root $(\mathrm{C})$ are shown in Fig. 4. The FTIR analysis (B/D) shows a broad band at around 3311 and $2918 \mathrm{~cm}^{-1}$ which 
Table 1 Soil analysis

\begin{tabular}{ll}
\hline Parameters & Range \\
\hline $\mathrm{pH}$ & 5.21 \\
Electrical conductivity (EC) & $0.12 \mathrm{dSm}^{-1}$ \\
Organic carbon (C) & $1.52 \%$ \\
Nitrogen (N) & $446.7 \mathrm{~kg} / \mathrm{ha}$ \\
Phosphorus (P) & $105.4 \mathrm{~kg} / \mathrm{ha}$ \\
Potassium (K) & $313.4 \mathrm{~kg} / \mathrm{ha}$ \\
Sulfur (S) & $6.5 \mathrm{ppm}$ \\
Iron (Fe) & $18.3 \mathrm{ppm}$ \\
Manganese (Mn) & $18.7 \mathrm{ppm}$ \\
Copper (Cu) & $6.17 \mathrm{ppm}$ \\
Zinc (Zn) & $9.95 \mathrm{ppm}$ \\
Boron (B) & $2.10 \mathrm{ppm}$ \\
\hline
\end{tabular}

Table 2 Organoleptic studies of D. gangeticum

\begin{tabular}{llll}
\hline Parameter & \multicolumn{2}{l}{ Organoleptic evaluation } \\
\cline { 2 - 3 } & Leaf & Stem & Root \\
\hline Taste & Sweet & Characteristic & Sweet \\
Odor & Characteristic & Characteristic & Characteristic \\
Color-upper/outer & Darkgreen & Light brown & Reddish brown \\
Color-lower/inner & Light green & Yellowish green & Light brown \\
Texture of powder & Coarse & Sandy & Coarse \\
Shape & Ovate-oblong & Angular & - \\
Surface & Hairy & Glabrous & Smooth
\end{tabular}

can be attributed to $\mathrm{O}-\mathrm{H}$ group present in phenols. These results indicated that the plant extracts are mainly rich in phenolic class of derivatives.

The ADME-PK properties of selected pterocarpans (1a-1d, Fig. 5) are recorded in Tables 5 and 6. It was shown that all the compounds have high gastrointestinal (GI) absorption, good blood-brain barrier (BBB) permeability, and also P-glycoprotein (P-gp) permeability. The lipophilicity $\left(\log \mathrm{P}_{\mathrm{o} / \mathrm{w}}\right)$ and skin permeation $(\log \mathrm{Kp})$ of compounds were observed in the range of 1.64-4.81 and $4.99-6.87 \mathrm{~cm} / \mathrm{s}$, respectively.

Furthermore, compounds 1a-d showed inhibition of cytochrome P450 isomers. Also, topological polar surface area (TPSA) of $\mathbf{1 a - c}$ was found to have 46.15-68.15 $\AA$ ( $\leq 140 \AA)$, indicating that compounds have appropriate oral bioavailability (0.55). Moreover, all compounds 1a-d meet the criteria of drug-likeness assessment based on Lipinski, Ghose, Veber, and Egan rules. The drug lead-likeness shows that compound desmocarpin (1c) is the most druggable substance without any violation. A combination of fragment contributions and a complexity penalty of $\mathbf{1 a - 1 d}$ indicated good synthetic accessibility.

\section{Discussion}

The pharmaco-chemical constituent in the crude drug is greatly influenced by geographic-climatic conditions, and external conditions such as light intensity, water availability, and soil composition affect both the quantitative and qualitative composition of metabolites [42]. Moreover, this might influence the chemical biology of drugs. The plant growth and development largely depend on the combination and concentration of mineral nutrients available in the soil [43]. A deficiency of any one of them may affect plant physiological functions, and it leads to changes in the pharmaco-chemical properties [44, 45]. Based on this aspect, we began pharmaco-chemical characterization of D. gangeticum with special reference to soil chemistry and geography.

Nutrients are considered essential for plants [46]; macronutrients are the building blocks of crucial cellular components like proteins and nucleic acids; as the name suggests, they are required in large quantities. Nitrogen $(\mathrm{N})$, phosphorus $(\mathrm{P})$, magnesium $(\mathrm{Mg})$, and potassium (K) are some of the most important macronutrients [47]. Carbon (C), hydrogen ( $\mathrm{H})$, and oxygen (O) are also considered macronutrients as they are required in large quantities to build the larger organic molecules of the cell [48].

The nutrients are usually obtained from the soil through plant roots. The soil nature and lack of nutrient availability in soil can make harder for plants to absorb required nutrients. In general, the soil $\mathrm{pH}$ is close to neutral and many plants grow successfully in a soil $\mathrm{pH}$ range of 5.5 to 7.5. The availability of plant nutrients is significantly affected by soil $\mathrm{pH}$ [49]. The soil of this region generally shows acidic in nature, high in nitrogen, and poor in bases; the texture is dark reddish-brown to black with loamy to silty loam [50]. In our present study, it was found that the soil $\mathrm{pH}$ was 5.21 and the electrical conductivity was $0.12 \mathrm{dSm}^{-1}$. The NPK analysis revealed moderately high content of nitrogen and very high content of phosphorus and potassium in the soil. Furthermore, sulfur content was found to be sufficient. Moreover, micronutrient analysis revealed sufficient contents of iron (18.3 ppm), manganese (18.7 ppm), copper (6.17 ppm), zinc $(9.95 \mathrm{ppm})$, and boron $(2.10 \mathrm{ppm})$. These micronutrients are required in very small amounts and often required as cofactors for enzyme activity.

We have taken a closer look at the above values and concluded that a sufficient amount of all essential macroand micronutrients is present in the soil. It helps with normal plant growth and development. These studies did not find any symptoms of nutrient deficiency, like stunted 

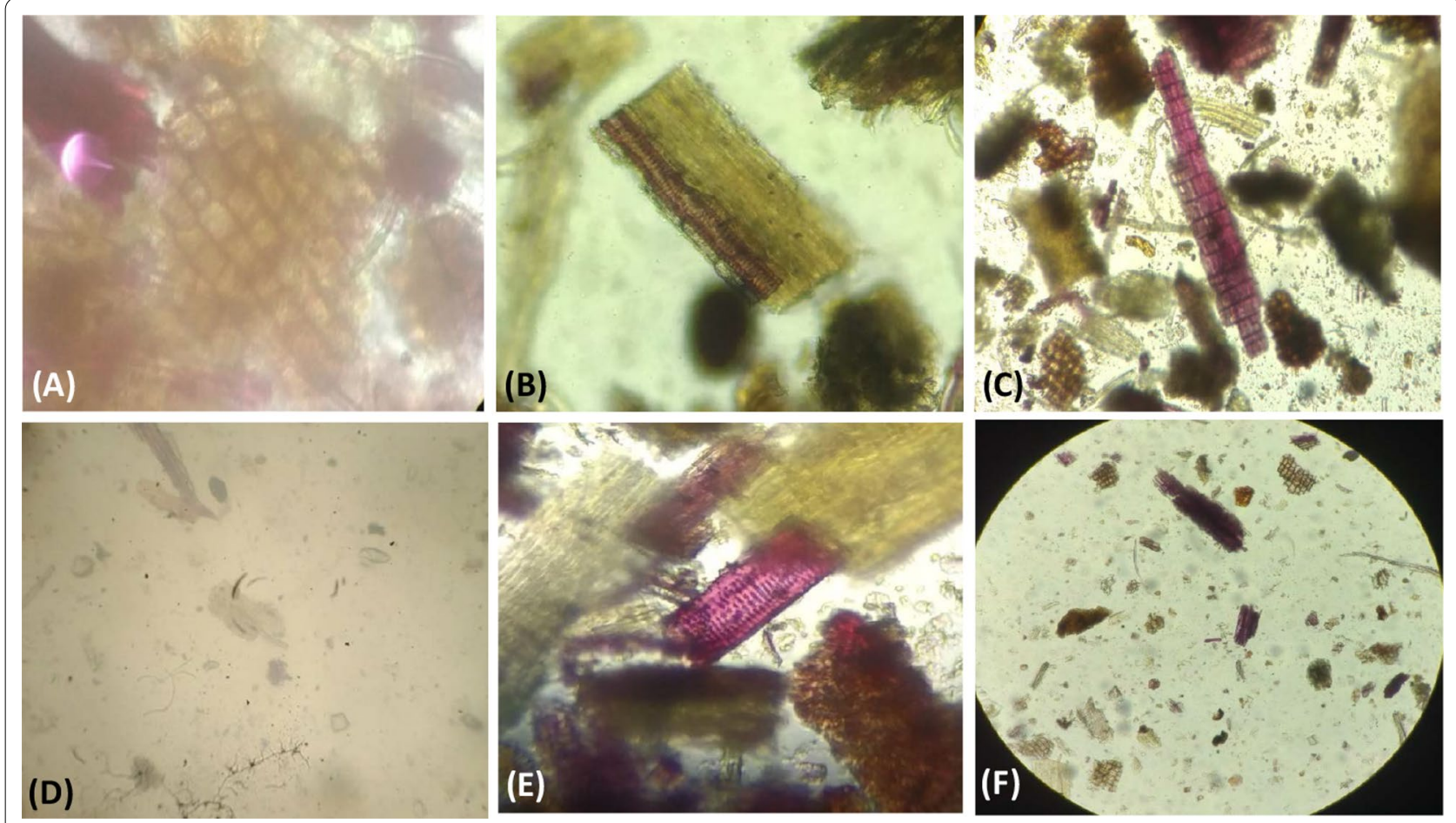

Fig. 2 Powder microscopy of D. Gangeticum. A Epidermis ( $\times 40)$, B tangentially elongated cork cells $(\times 40)$, C separated fiber ( $\times 40)$, D prismatic crystals of calcium oxalate $(x 40), \mathbf{E}$ pitted vessel $(x 40)$, $\mathbf{F}$ simple fibers $(x 40)$

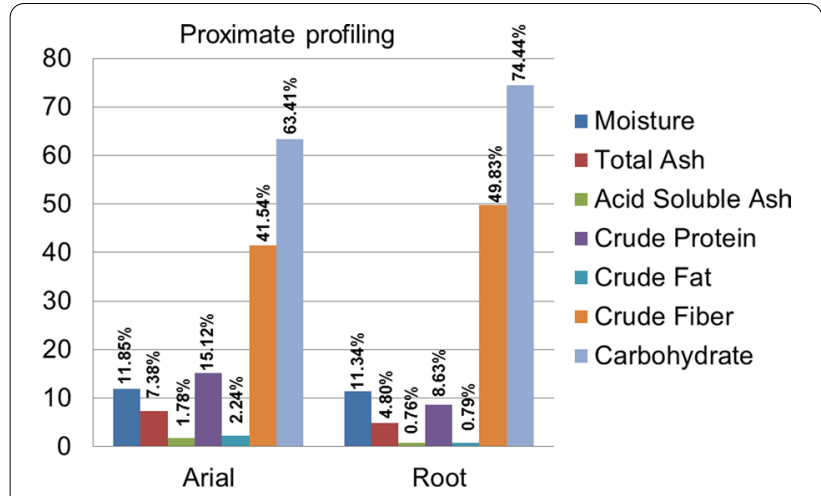

Fig. 3 Proximate profiling of crude powder of D. gangeticum (L.) DC.

Table 3 Extractive yield analysis

\begin{tabular}{lll}
\hline Extract & \multicolumn{2}{l}{ Yield (\%) $^{\mathbf{a}}$} \\
\cline { 2 - 3 } & Aerial & Root \\
\hline Ethanol & $5.8 \pm 0.01$ & $4.80 \pm 0.02$ \\
Water & $8.8 \pm 0.12$ & $7.20 \pm 0.10$ \\
Hexane & $2.9 \pm 0.01$ & $2.50 \pm 0.02$ \\
Ethyl acetate & $3.2 \pm 0.03$ & $2.60 \pm 0.01$ \\
\hline
\end{tabular}

${ }^{\text {a }}$ Mean of 3 readings \pm SEM
Table 4 Phytochemical screening of ethanolic extracts of aerial and root

\begin{tabular}{lcc}
\hline Phytochemical compounds & Aerial & Root \\
\hline Tannins & - & - \\
Glycoside & + & + \\
Amino acid & + & + \\
Phenols & + & + \\
Volatile oils & - & - \\
Alkaloids & + & + \\
Saponins & - & - \\
Flavonoids & + & + \\
Coumarins & + & + \\
Phytosterols & - & - \\
Triterpenoids & - & +
\end{tabular}

(+), present; (-), absent

growth, death of plant tissue, or yellowing of the leaves caused by a reduced production of chlorophyll, a pigment needed for photosynthesis. Additionally, the root structure was found to be normal. In general, nutrient-limited soils are a change in root structure that may increase the overall surface area of the root to increase nutrient acquisition or may increase elongation of the root system to access new nutrient sources [51]. 


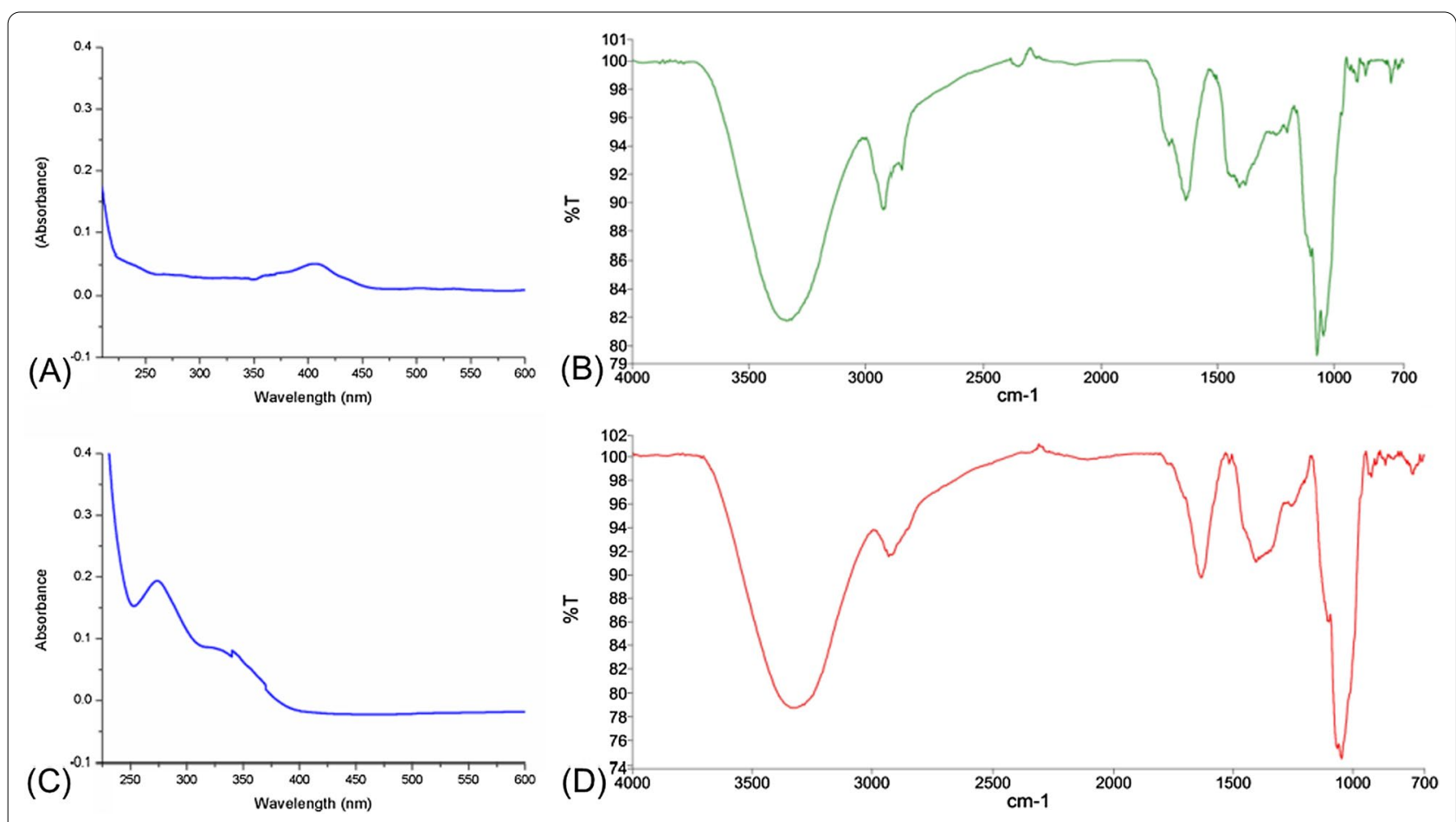

Fig. 4 UV and FTIR profiling of EtOH extracts; aerial (A, C); root (B, D)

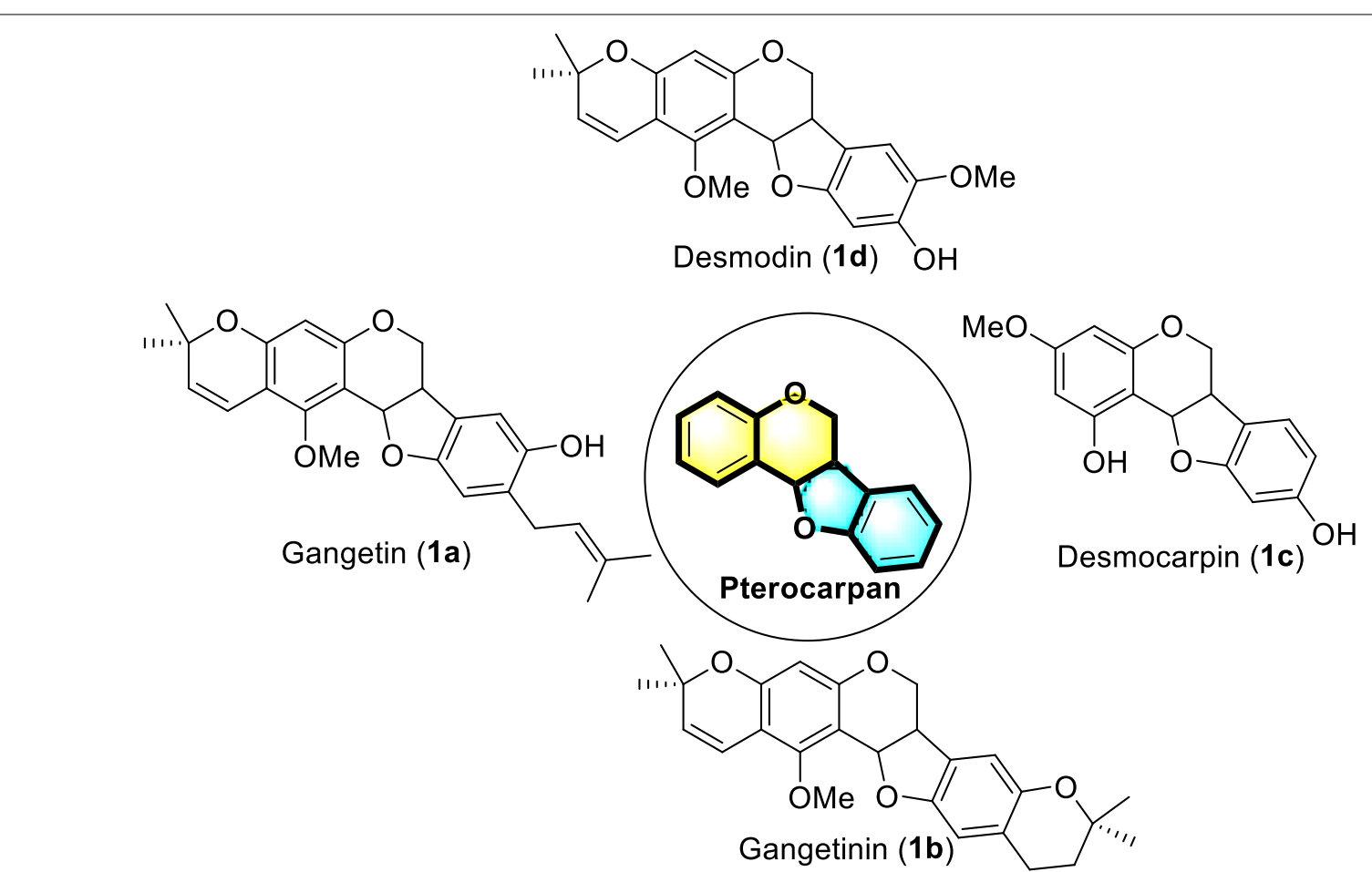

Fig. 5 Selected pterocarpan derivatives from D. gangeticum (L.) DC. 
Table 5 Pharmacokinetic studies of pterocarpans

\begin{tabular}{|c|c|c|c|c|c|c|c|c|c|c|}
\hline \multicolumn{11}{|c|}{ Pharmacokinetics properties } \\
\hline \multicolumn{2}{|c|}{ Gl absorption } & \multirow{3}{*}{$\begin{array}{l}\text { BBB } \\
\text { permeation } \\
\text { Yes }\end{array}$} & \multirow{3}{*}{$\begin{array}{l}\log p_{\mathrm{o} / \mathrm{w}} \\
4.81\end{array}$} & \multirow{3}{*}{$\begin{array}{l}\text { P-gp } \\
\text { Yes }\end{array}$} & \multicolumn{5}{|c|}{ Inhibition of cytochrome P450 } & \multirow{3}{*}{$\begin{array}{l}\log K p \\
-4.99 \mathrm{~cm} / \mathrm{s}\end{array}$} \\
\hline & & & & & \multirow{2}{*}{$\begin{array}{l}\text { CYP1A2 } \\
\times\end{array}$} & \multirow{2}{*}{$\frac{\text { CYP2C19 }}{\sqrt{ }}$} & \multirow{2}{*}{$\frac{\text { CYP2C9 }}{\sqrt{ }}$} & \multirow{2}{*}{$\begin{array}{l}\text { CYP3A4 } \\
\times\end{array}$} & \multirow{2}{*}{$\frac{\text { CYP2D6 }}{\sqrt{ }}$} & \\
\hline $1 \mathrm{a}$ & High & & & & & & & & & \\
\hline $1 b$ & High & Yes & 4.71 & Yes & $x$ & $\sqrt{ }$ & $\sqrt{ }$ & $\sqrt{ }$ & $\sqrt{ }$ & $-5.41 \mathrm{~cm} / \mathrm{s}$ \\
\hline $1 c$ & High & Yes & 1.64 & Yes & $x$ & $x$ & $\times$ & $\sqrt{ }$ & $\times$ & $-6.87 \mathrm{~cm} / \mathrm{s}$ \\
\hline $1 d$ & High & Yes & 3.36 & Yes & $\sqrt{ }$ & $\sqrt{ }$ & $\sqrt{ }$ & $\sqrt{ }$ & $\sqrt{ }$ & $-6.15 \mathrm{~cm} / \mathrm{s}$ \\
\hline
\end{tabular}

1a, gangetin; 1b, gangetinin; 1c, desmocarpin; 1d, desmodin; Gl, gastrointestinal absorption; BBB, blood-brain barrier permeability; Log $P_{\mathrm{o} / w^{\prime}}$ lipophilicity; P-gp,

P-glycoprotein substrate; Log Kp, skin permeation

Table 6 Drug-likeness and medicinal chemistry of pterocapans

\begin{tabular}{|c|c|c|c|c|c|c|c|c|c|c|c|}
\hline \multicolumn{12}{|c|}{ Drug-likeness and medicinal chemistry } \\
\hline \multicolumn{2}{|c|}{$\log s$} & \multicolumn{5}{|c|}{ Drug-likeness } & \multirow[t]{2}{*}{ Bioavailability } & \multicolumn{3}{|c|}{ Medicinal properties } & \multirow{2}{*}{$\begin{array}{l}\text { Synthetic } \\
\text { accessibility }\end{array}$} \\
\hline & & Lipinski & Ghose & Veber & Egan & Mugge & & TPSA $\left(A^{2}\right)$ & PAINS (alert) & Lead likeness & \\
\hline $1 \mathrm{a}$ & -5.98 & $\sqrt{ }$ & $\sqrt{ }$ & $\sqrt{ }$ & $\sqrt{ }$ & $x$ & 0.55 & 57.15 & 0 & $\mathrm{No}^{\mathrm{a}}$ & 4.94 \\
\hline $1 b$ & -5.74 & $\sqrt{ }$ & $\sqrt{ }$ & $\sqrt{ }$ & $\sqrt{ }$ & $\sqrt{ }$ & 0.55 & 46.15 & 0 & $\mathrm{No}^{\mathrm{a}}$ & 4.90 \\
\hline $1 c$ & -2.82 & $\sqrt{ }$ & $\sqrt{ }$ & $\sqrt{ }$ & $\sqrt{ }$ & $\sqrt{ }$ & 0.55 & 68.15 & 0 & Yes & 4.38 \\
\hline $1 d$ & -4.60 & $\sqrt{ }$ & $\sqrt{ }$ & $\sqrt{ }$ & $\sqrt{ }$ & $\sqrt{ }$ & 0.55 & 66.38 & 0 & $\mathrm{No}^{\mathrm{a}}$ & 4.57 \\
\hline
\end{tabular}

1a, gangetin; 1b, gangetinin; 1 1c, desmocarpin; 1d, desmodin; Log s, solubility class; TPSA, topological polar surface area; PAINS, pan-assay interference structure

${ }^{\text {a }}$ Molecular weight $<350$

In herbal formulation, the proper identity of many drug species is important [52]. A single plant species has several different commercial or medicinal names in different regions. However, authentication of the botanical identity and ascertaining the genuineness of drug is a great concern in practical situation. To some extent, it can be overcome by drug characterization. This is done by estimating their active principles [53]. There are many advanced approaches available to authenticate botanical drugs, ranging from simple morphological examination to physical and biochemical analysis, chromatographic, and molecular techniques [54]. Among these, powder microscopy is the most practical method for primary authentication [55], and it is a unique, valuable, rapid, and cost-effective assessment tool and plays an important role in the authentication and assessment of herbal plants [56]. The powder microscopy reveals the presence of various parts such as epidermis, tangentially elongated cork cells, separated fiber, prismatic crystals of calcium oxalate, pitted vessel, and simple fibers. These features are useful in identifying species with similar morphological characters.

DNA barcoding has been a powerful tool for plant species identification in recent years due to its simplicity and high accuracy as compared to the complexity and subjective biases associated with morphology-based identification of taxa. This technique is reliable and is not affected by external factors such as climates, age, or plant part [57]. We have used the ribulose-1,5-bisphosphate carboxylase/oxygenase large subunit $(r b c L)$ molecular marker for plant species identification. The results showed that the sequence was $99.77 \%$ similar to D. gangeticum with $100 \%$ query coverage. Previously, the $r b c L$ markers were successfully used to identify many medicinal plants $[58,59]$. Therefore, results also provide the $r b c L$ as an important universal molecular marker for medicinal plant identification.

In our preliminary field investigation, it is revealed that this plant is used to cure various ailments in the tribal people communities of the Western Ghats region of Kerala; therefore, interest was developed to know other possible health benefits of this plant. Besides using such plants as a crude drug, proximate profiling can be essential. The proteins, fats, and carbohydrates are important nutrients to be assessed in the medicinal plant. These proteins enclose essential amino acids and have nutritional values for human health [60].

The physicochemical parameters such as percentage of moisture content, total ash, and acid insoluble ash were established. The successive Soxhlet extractive yields 
obtained from water, followed by ethanol, ethyl acetate, and hexane, are calculated. In the future, the optimal ash and extractive values help to identify the inorganic substance or impurities present along with the crude drug. Overall, this leads to quality improvement in the drug.

The proximate parameters such as percentage of crude fiber, crude protein, crude fat, and carbohydrate contents of the areal and root are also evaluated, and the areal part has a high content of crude fiber, crude protein, crude fat, and carbohydrate. The root part was found to have only less content of protein $(8.63 \%)$ and crude fat $(0.73 \%)$. The crude fiber $(49.83 \%)$ and carbohydrate $(74.44 \%)$ were found to have the highest percent. These findings help to set up certain standards for crude drugs and the determination of nutritive values. Reports suggest that medicinal plant species have their nutrient/proximate composition besides having bioactive constituents. These nutrients are essential for the physiological functions of the human body [61].

The results of the phytochemical profiling showed that the ethanolic extract of the aerial part contained glycoside, amino acid, phenols, alkaloids, flavonoids, and coumarins, while the ethanolic root extract of the plant revealed the presence of glycoside, amino acid, phenols, alkaloids, flavonoids, coumarins, and triterpenoids. Moreover, our FTIR analysis gave an idea about the plant extracts mainly rich in phenolic derivatives.

The compounds such as gangetin (1a), gangetinin (1) $)$, desmocarpin (1c), and desmodin (1d) are belonging to pterocarpan class of phenolic derivatives which was reported from the species D. gangeticum [13]. The pterocarpans constitute the second largest group of natural isoflavonoids and show many biological properties [62]. The main structural feature of pterocarpans consists in the presence of a tetracyclic system of benzofuran-benzopyran rings [63].

In this context, we tried to understand the absorption, distribution, metabolism, and excretion (ADME) properties of pterocarpans (1a-1d), through a silicon study. The computer modeling of ADME properties of compounds provides an idea about structure-property relationships and drug metabolism and pharmacokinetics properties based on the compound structure [64]. Results revealed that all pterocarpans $(\mathbf{1 a}-\mathbf{1 d})$ showed high gastrointestinal (GI) absorption and good bloodbrain barrier (BBB) permeability, and also compounds have $\mathrm{P}$-glycoprotein (P-gp) permeability. The lipophilicity $\left(\log \mathrm{P}_{\mathrm{o} / \mathrm{w}}\right)$ and skin permeation $(\log \mathrm{Kp})$ of compounds were observed in the range of 1.64-4.81 and $4.99-6.87 \mathrm{~cm} / \mathrm{s}$, respectively. Furthermore, compounds 1a-d showed inhibition of cytochrome P450 isomers. Topological polar surface area (TPSA) is the sum of polar atoms present in the molecule $(\mathbf{1 a}-\mathbf{c})$ surface, and it helps to predict drug transport qualities such as intestinal absorption and BBB penetration. The TPSA of 1a-c was found to be 46.15-68.15 $(\leq 140 \AA)$. This value indicates good blood-brain barrier penetration. Moreover, all compounds $\mathbf{1 a}-\mathbf{d}$ meet the criteria of drug-likeness assessment based on Lipinski, Ghose, Veber, and Egan rules. The drug lead-likeness shows that compound desmocarpin (1c) is the most druggable substance without any violation. A combination of fragment contributions and a complexity penalty of $\mathbf{1 a - 1 d}$ indicated good synthetic accessibility.

\section{Conclusion}

The pharmaco-chemical features like organoleptic, DNA sequence, physicochemical, proximate, phytochemical, UV, and FTIR profiling, ADME-PK properties, and soil chemistry of D. gangeticum revealed its unique and diagnostic peculiarities. DNA barcoding showed that the sequence was $99.77 \%$ similar to $D$. gangeticum (KP094638) having 100\% query coverage. The soil analysis revealed the presence of moderately high content of NPK and sufficient amount of all essential macro- and micronutrients. The phytochemical profiling showed important class of phytoconstituents in the aerial and root parts of the plant. FTIR profiling indicates that the plant extracts are mainly rich in phenolic derivatives. Further, ADME-PK properties of selected pterocarpan such as gangetin (1a), gangetinin (1b), desmocarpin (1c), and desmodin (1d) were found to pass the Lipinski, Ghose, Veber, and Egan rules, supporting the drug-likeliness. This useful information helps future works on this species.

\section{Abbreviations}

ADME-PK: Absorption, distribution, metabolism, excretion-pharmacokinetics; CTAB: Cetyltrimethylammonium bromide; PCR: Polymerase chain reaction; ATR-FTIR: Attenuated total reflectance Fourier-transform infrared spectrometer; SMILES: Simplified molecular-input line-entry system; CYP: Cytochrome P450; Gl: Gastrointestinal absorption; BBB: Blood-brain barrier; TPSA: Topological polar surface area; PAINS: Pan-assay interference structure.

\section{Acknowledgements}

The authors acknowledge all contributors for their valuable time and commitment to the study. This research received no external funding in part of it.

\section{Authors' contributions}

PKM and TPA planned and designed the experiments and performed the data analysis. PKM performed and designed the experiments. TSK and BDRK collaborated with the preparation of the manuscript and critical analyses of the text. All authors read and approved the final manuscript.

\section{Funding}

No funding was received during the study. The study was done through self-finance.

Availability of data and materials

Data and material are available upon request 


\section{Declarations}

Ethics approval and consent to participate

Not applicable.

\section{Consent for publication}

Not applicable.

\section{Competing interests}

The authors declare that they have no competing interests.

\section{Plant authentication}

Healthy and disease-free plants of $D$. gangeticum were collected from the Idukki District of Kerala, India, during March-April 2019. The collected specimens were identified by using DNA barcoding, and the sequences were compared by using BLAST results. The confirmed sequences were submitted to the NCBI GenBank, and the sequence was given an accession number MW021162.

\section{Author details}

${ }^{1}$ Department of Botany, Bharathidasan University, Tiruchirappalli, Tamil Nadu 620 024, India. ${ }^{2}$ School of Chemistry, Bharathidasan University, Tiruchirappalli, Tamil Nadu 620 024, India.

Received: 20 May 2021 Accepted: 5 October 2021

Published online: 17 October 2021

\section{References}

1. Suntar I (2019) Importance of ethnopharmacological studies in drug discovery: role of medicinal plants. Phytochem Rev 19:1199-1209

2. Wink M (2015) Modes of action of herbal medicines and plant secondary metabolites. Med (Basel) 2:251-286

3. Martins E (2013) The growing use of herbal medicines: issues relating to adverse reactions and challenges in monitoring safety. Front Pharm 4:177

4. Lim XY, The BP, Tan TYC (2021) Medicinal plants in COVID-19: potential and limitations. Front Pharmacol 12:355

5. Ahmad S, Zahiruddin S, Parveen B, Basist P, Parveen A, Gaurav PR, Ahmad $M$ (2021) Indian medicinal plants and formulations and their potential against COVID-19_-preclinical and clinical research. Front Pharmacol $11: 2470$

6. Pushpesh KM, Nasib S, Ghufran A, Anuradha D, Rakesh M (2005) Glycolipids and other constituents from Desmodium gangeticum with antileishmanial and immunomodulatory activities. Bioorg Med Chem Lett 15:4543-4546

7. Sebua SS, Alfred M (2018) Data on medicinal plants used to treat respiratory infections and related symptoms in South Africa. J Data Bri 21:419-423

8. Laura López R, Julia CW, Tanausú Vega M, Nigel G (2020) Central nervous system activities of extract Mangifera indica L. J Eth pharm 260:1-16

9. Ian EC, Sandy FV (2020) The traditional use of southern African medicinal plants in the treatment of viral respiratory diseases: a review of the ethnobotany and scientific evaluations. J Eth pharm 262:1-24

10. Palit P (2018) Bioactivity-guided phytofractions. Nat Prod Drug Discov 57-71

11. Kunle O, Folashade E, Henry O, Ahmadu PO (2012) Standardization of herbal medicines - a review. Int J Biod Cons 3:101-112

12. Trout K (1997) Trout's notes on the genus Desmodium. Better Days Publishing, pp 1-38

13. Subha R, Madan MP, Ajay KSR (2011) An ethnomedicinal, phytochemical and pharmacological profile of Desmodium gangeticum (L.) DC. and Desmodium adscendens (Sw.) DC. J Eth pharm 136:283-296

14. Toyigbénan BF, Raphiou M, Marcellin A, Durand DN, Aklesso N, Sylvestre A, Haziz S, Adolphe A, Aly S, Lamine BM (2018) Ethnobotanical Survey of three species of Desmodium genus(Desmodium ramosissimum, Desmodium gangeticum and Desmodium adscendens) used in traditional medicine, Benin. Int J Sci 7:26-29
15. Xueqin M, Chengjian Z, Changling H, Khalid R, Luping Q (2011) The genus Desmodium (Fabaceae)-traditional uses in Chinese medicine, phytochemistry and pharmacology. J Eth pharmacol 138:314-332

16. Prasobh KM, Anil KM, Senthil TK, Kumari BDR (2020) A comprehensive review of the phytochemical and pharmacological properties of Desmodium gangeticum (L.) DC. J Adv Sci Res 11(4):90-97

17. Prayagadatta S (1966) Sharangadhra Samhita. Chowkhamba Sanskrita Academy, pp 1192-1194

18. Warrier PK, Nambiar VPK, Ramankutty C (1995) Indian medicinal plants: A compendium of 500 species, vol 3. Oricat Longman Pvt Ltd, pp 38-42

19. Chanda S (2014) Importance of pharmacognostic study of medicinal plants: an overview. J Pharm Phytochem 2:69-73

20. Cheynier V, Comte G, Davies KM, Lattanzio V, Martens S (2013) Plant phenolics: recent advances on their biosynthesis, genetics, and ecophysiology. Plant Physio Biochem 72:1-20

21. Ramakrishnan M, Ceasar SA, Duraipandiyan V, Vinod K, Kalpana K, Al-Dhabi N, Ignacimuthu S (2016) Tracing QTL for leaf blast resistance and agronomic performance of finger millet (Eleusine Coracana (L.) Gaertn.) genotypes through association mapping and in silico comparative genomics analyses. PLOS ONE 7:e0159264

22. Hall TA (1999) BioEdit: a user-friendly biological sequence alignment editor and analysis program for Windows 95/98/NT. In: Nucleic acids symposium series 41. Oxford University Press, pp 95-98

23. Wright ES, Yilmaz LS, Noguera DR (2012) DECIPHER a search-based approach to chimera identification for $16 \mathrm{~S}$ rRNA sequences. Appl Environ Microbiol 78:717-725

24. Benson DA, Karsch-Mizrachi I, Lipman DJ, Ostell J, Wheeler DL (2005) GenBank Nuc Acids Res 33:D34-D38

25. Black AL (1973) Soil property changes associated with crop residue management in a wheat-fallow rotation. Soil Sci Soc Amer Proce 37:943-946

26. Soil Science Society of China (1999) Analysis methods of soil agricultural chemistry (in Chinese). Chin Agri Sci Tech Press, Beijing, pp 86-87

27. Walkley A, Black IA (1934) An examination of the Degtjareff method for determining soil organic matter and a proposed modification of the chromic soil titration method. Soil Sci 37:30-38

28. Parkinson JA, Allen SE (1975) A wet digestion procedure suitable for the determination of nitrogen and mineral nutrients in biological material. Commun Soil Sci Plant Anal 6:1-11

29. Murphy J, Riley JP (1962) A modified single solution method for the determination of phosphate in natural waters. Anal Chimi Acta 27:31-36

30. Kalra PY (1998) Handbook on reference method for soil and plant analysis. CRC Press

31. Wallis T (1985) Unorganized drugs. Text Pharmacog 467-469

32. Evans WC (2009) Trease and Evans' pharmacognosy e-book. Else Heal Scien, 16th edn. Else Limit, pp 133-135

33. Vermani A, Navneet $P$, Chauhan A (2010) Physico-chemical analysis of ash of some medicinal plants growing in Uttarakhand, India. Nat Sci 8:88-91

34. AOAC (2016) Official methods of analysis of AOAC International. 20th edn. Rockville, Maryland

35. Harborne JB (1991) Phytochemical screening-guide to modern techniques of plant analysis. Chapman and Hall

36. Zoete V, Daina A, Bovigny C, Michielin O (2016) SwissSimilarity: a web tool for low to ultra high throughput ligand-based virtual screening. J Chem Info Mod 56:1399-1404

37. Daina A, Michielin O, Zoete V (2017) SwissADME: a free web tool to evaluate pharmacokinetics, drug-likeness and medicinal chemistry friendliness of small molecules. Scient Rep 7:427-517

38. Lipinski CA, Lombardo F, Dominy BW, Feeney PJ (1997) Experimental and computational approaches to estimate solubility and permeability in drug discovery and development settings. Adv Drug Del Rev 23:3-25

39. Ghose AK, Viswanadhan VN, Wendoloski JJ (1999) A knowledge-based approach in designing combinatorial or medicinal chemistry libraries for drug discovery. 1. A qualitative and quantitative characterization of known drug databases. J Comb Chem 1:55-68

40. Veber DF, Johnson SR, Cheng HY, Smith BR, Ward KW, Kopple KD (2002) Molecular properties that influence the oral bioavailability of drug candidates. J Med Chem 45:2615-2623

41. Cortes C, VapnikV (1995) Machine learning. Support vect net 20:273-297

42. Gouvinhas I, Pinto R, Santos R, Saavedra MJ, Barros Al (2020) Enhanced phytochemical composition and biological activities of grape (Vitis vinifera L.) Stems growing in low altitude regions. Scien Hort 265:1-8 
43. Chen Y, Aviad T (1990) Effects of humic substances on plant growth, vol 7. ACSESS Publications, pp 161-186

44. Sunayana N, Sandeep R, Ranbeer SR, Indra DB, Bhawana P, Fulekar MH (2017) Soil constituents influence accumulation of phytochemicals and nutritional content in Wrightia tinctoria of North Gujarat, India. Ind J Plant Physiol 22(2):197-205

45. Jimoh MO, Afolayan AJ, Lewu FB (2019) Antioxidant and phytochemical activities of Amaranthus caudatus L. harvested from different soils at various growth stages. Sci Rep 9(1):1-4

46. White PJ, Brown PH (2010) Plant nutrition for sustainable development and global health. Ann Bot 105(7):1073-1080

47. Maathuis FJM (2009) Physiological functions of mineral macronutrients. Cur Op Plant Biol 12:250-258

48. Das R, Dash BP (2001) Principles of plant nutrition. New Dimension for Crop Sci 1-185

49. Neina $\mathrm{D}$ (2019) The role of soil $\mathrm{pH}$ in plant nutrition and soil remediation. Appl Env Soil Sci 2019:1-10

50. Raju K, Anil Kumar R (2006) Land use changes in Udumbanchola taluk, Idukki district-Kerala: an analysis with the application of remote sensing data. J Ind Soc Rem Sens 2:161-169

51. Jose LB, Alfredo CR, Luis HE (2003) The role of nutrient availability in regulating root architecture. Cur Opin Plant Biol 6:280-287

52. Mukherjee PK (2019) Quality assurance of herbal drugs and stability testing. Qual Contr Eval Herb Dr 685-705

53. Balunas MJ, Kinghorn AD (2005) Drug discovery from medicinal plants. Life Sci 5:431-441

54. Revathy SS, Rathinamala R, Murugesan M (2012) Authentication methods for drugs used in Ayurveda, Siddha and Unani systems of medicine: an overview. Int j pharma sci res 1:2352-2361

55. Zhao ZZ, Hu YN, Wong YW, Gigi Wong WC, Wu K, Jiang ZH (2005) Application of microscopy in authentication of Chinese patent medicine-Bo Ying compound. Microsc Res Tech 67:305-311
56. Singh D, Aeri V, Ananthanarayana DB (2018) Development of internet technology TIPHAM (Tool for identity of Powdered Herbals through Analytical Microscopy) for microscopic identification of crude herbal drugs. Pharmacog Mag 14:213

57. Mohammed Abubakar B, Mohd Salleh F, Shamsir Omar MS, Wagiran A (2017) DNA barcoding and chromatography fingerprints for the authentication of botanicals in herbal medicinal products. Evidence-Based Compl Alt Med 2017:1-29

58. Linda IE, Oghenetega JA, Eferhire A, Akpovwehwee AA, Chosen O, George NU, Nyerhovwo JT (2020) Isolation, identification and in silico analysis of bitter leaves (Vernonia amygdalina) ribulose-1,5-bisphosphate carboxylase/ oxygenase gene. Gen Rep 20:1-29

59. Alaklabi A, Ahamed RN, Qthanin Al, Arif IA, Panneerselvam A, Al-Khulaid A (2020) Molecular characterization of endangered endemic plant Aloe pseudorubroviolacea using chloroplast matK and plastid rbcL gene. Saud J Biol Sci 28:1123-1127

60. Rajni K, Vikas N (2018) Proximate composition, nutritional profile and health benefits of legumes - a review. Leg Res An Int J 41:325-332

61. Jew S, Antoine JM, Bourlioux P, Milner J, Tapsell LC, Yang Y, Jones PJH (2015) Nutrient essentiality revisited. J Funct Foods 14:203-209

62. Leticia JG, Miriam AC, Manuel MD, Ignacio RG (2007) Pterocarpans: interesting natural products with antifungal activity and other biological properties. Phytochem Rev 7:125-154

63. Daniel M, Purkayastha RP (1995) Handbook of phytoalexin metabolism and action. Mol Nutr Food Res 39:253-253

64. Eddershaw PJ, Beresford AP, Bayliss MK (2000) ADME/PK as part of a rational approach to drug discovery. Drug Disc Tod 5:409-414

\section{Publisher's Note}

Springer Nature remains neutral with regard to jurisdictional claims in published maps and institutional affiliations.

\section{Submit your manuscript to a SpringerOpen ${ }^{\circ}$ journal and benefit from:}

- Convenient online submission

- Rigorous peer review

- Open access: articles freely available online

- High visibility within the field

- Retaining the copyright to your article

Submit your next manuscript at $\boldsymbol{\nabla}$ springeropen.com 